\section{Alvorlige psykiske lidelser og samfunnets betydning}

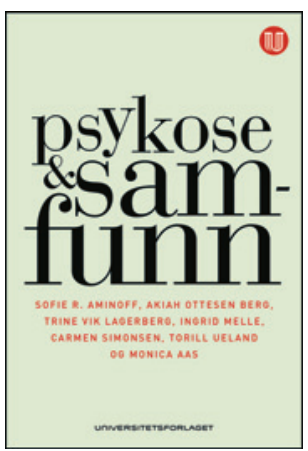

\section{Nevrobiologisk perspektiv på psykoterapiens virkningsmekanismer}

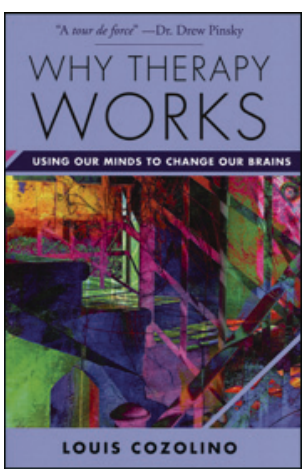

\author{
Louis Cozolino
}

\section{Why therapy works}

Using our minds to change our brains. $288 \mathrm{~s}$. New York, NY: W.W. Norton \& Company, 2016 Pris USD 24 ISBN 978-0-393-70905-6
Denne utgivelsen springer ut fra Norment K.G. Jebsens senter for psykoseforskning, Norment, og er rettet mot studenter og praktikere innenfor psykisk helsevern. Målsettingen er å gi et bredt bilde av psykotiske lidelser, med særlig vekt på psykososiale miljøfaktorer.

Det er syv selvstendige kapitler og en avsluttende kommentar. Boken starter med en beskrivelse av hva som legges i begrepet «psykoselidelser»: diagnostikk og biologiske funn. Deretter drøftes betydningen av risikofaktorer som urbanitet, barndomstraumer, migrasjon, etniske minoriteter og rus. Samfunnets betydning for utvikling og forløp, og ikke minst symptombedring, versus funksjon i utdanning og arbeid, er viet god plass. Det hele avrundes med en oppsumering/ avsluttende kommentar. Språket er konsist og godt, og illustrasjoner og tenkebokser er nennsomt plassert i teksten.

Psykose er ikke en egen diagnose. Det er psykotiske symptomer ved en rekke lidelser, særlig bipolar I-lidelser, schizofrenier og paranoide psykoser. Både kunnskaper om symptomer, utbredelse, arv og miljø samt biologiske tegn peker mer mot det som er felles enn det som er forskjellig for disse lidelsene, noe som rettferdiggjør bokens vinkling. Forfatterne hevder at biologisk forskning så langt ikke har klart å gi noe entydig svar på risiko, årsakssammenhenger og utvikling eller forløp av psykoselidelser. Et av de mest bastante funnene er at arvelighet spiller en stor, men ikke deterministisk rolle. Man vet at risikoen for å bli syk er større jo nærmere i slekt man er - opptil over $50 \%$ hos eneggede tvillinger. Men det viktige spørsmålet er jo hvorfor mer enn halvparten av nære slektninger til pasienter med psykoselidelser faktisk selv ikke blir syke.

Hvordan går det med pasientene? Forskningen på hvilke miljøfaktorer som er av størst betydning for bedring og funksjonsgjenvinning er i dag mangelfull, og forfatterne viser at det kanskje viktigste feltet for selvrealisering, nemlig deltagelse i arbeidslivet, er lav hos de syke.

Hva kan vi lære om negative og beskyttende faktorer i miljøet?

Resultatene er fortsatt relativt uspesifikke, på samme måte som man finner at en lang rekke gener bidrar til sårbarhet for både schizofreni og bipolar lidelse.

I en diskusjon om samfunnsforholdenes betydning for forekomst av psykoselidelser savner man en nærmere fremstilling om endringer i forekomst i forhold til endringer i samfunnet over tid, under konflikter og mellom kulturer. Er det mer eller mindre nå enn i tidligere tider?

Hver forfatter har ansvar for hvert sitt kapittel samt en felles avsluttende kommentar. Men det kan lett bli mye overlapping når hver enkelt skal presentere bakgrunn og rammeverk rundt sitt emne, særlig når disse som her er relativt nær beslektet.

\section{Fred Holsten}

Professor emeritus, Universitetet i Bergen
Forfatterens utgangspunkt er at han på tross av sin brede psykoterapeutiske utdanning ikke synes han har kunnet forklare psykoterapiens virkningsmekanismer på noen presis måte. I denne boken søker han etter svar i evolusjonsbiologien og nevrobiologien.

Det beskrives hvordan evolusjonen har gjort vår hjerne ekstremt sårbar for dysregulering, dissosiasjon og tankefeil. De primitive ikkeverbale og raske systemene for sansing, bevegelse og kroppslige prosesser er utilgjengelige for bevisst refleksjon og omtales som det ubevisste, som implisitt hukommelse og somatisk hukommelse. Mens hjernen behandler sensorisk, motorisk og emosjonell informasjon i løpet av 10-50 millisekunder, krever bevisst prosessering 500-600 millisekunder. Et halvt sekund er lang tid når det gjelder nevral kommunikasjon, men forskjellen kan knapt registreres bevisst. I løpet av det halve sekundet skanner hjernen kropp, hukommelse og emosjoner for relevant informasjon og konstruerer den aktuelle erfaringen over en templat fra fortiden. Idet vi blir oss bevisst en opplevelse, har den vært prosessert mange ganger, minner er aktivert og komplekse atferdsmønstre initiert. Ifølge forfatteren kaster denne forskjellen i prosesseringshastighet mellom ubevisste og bevisste systemer lys over det sentrale kliniske begrepet overføring.

Tilknytning mellom foreldre og barn vokste frem gjennom naturlig seleksjon fordi den økte barnets og familiegruppens sjanse for å overleve. Nevrobiologisk forskning tyder på at psykoterapeuten kan bidra til endring i utrygge tilknytningsskjemaer ved å være den foreldrefiguren pasienten har manglet, over et stykke tid. Tilknytningen til terapeuten vil etter hvert svekke implisitt hukommelse om emosjonell krenkelse i nære relasjoner. Båndet reduserer pasientens aktivering og angst og fremmer dermed læring som styrker kortikal hemning av kamp-flukt-reaksjonen. Psykoterapiforskningen understreker relasjonens sentrale betydning, men har ikke gitt noe omforent svar på spørsmålet om hvorfor den er viktig. Cozolino argumenterer ganske overbevisende for at viktige deler av svaret må søkes på nevrobiologisk nivå.

Why therapy works er skrevet for det allmenne publikum og inneholder ingen referanser eller litteraturliste, noe den etter min oppfatning ville tjent på. Det går ikke alltid klart frem når forfatteren refererer empiriske funn og når han presenterer hypoteser. Dette er imidlertid en meget velskrevet, perspektivrik og tankevekkende bok som klinikere og forskere på psykoterapifeltet vil ha stor glede av.

\section{Erik Falkum}

Professor, Seksjon for behandlingsforskning Avdeling for forskning og utvikling Klinikk for psykisk helse og avhengighet Oslo universitetssykehus 